\title{
OPTIMASI LAJU PENGERJAAN MATERIAL AISI P20 PROSES ELECTRICAL DISCHARGE MACHINING (EDM) SINKING MENGGUNAKAN METODE TAGUCHI
}

\author{
Farizi Rachman', Dhika Aditya Purnomo², Tri Andi Setiawan², \\ Ridhani Anita Fajardini ${ }^{4}$ \\ ${ }^{1234}$ Program Studi Teknik Desain dan Manufaktur, Politeknik Perkapalan Negeri Surabaya \\ Email : farizirachman@ppns.ac.id
}

\begin{abstract}
ABSTRAK
Electrical Discharge Machining atau EDM merupakan proses permesinan nonkonvensional. Sistem kerja EDM dengan memanfaatkan energi panas dari proses loncatan bunga api listrik (spark) akibat adanya perbedaan muatan di antara elektroda dan benda kerja yang terisi cairan dielektrik. EDM sinking secara digunakan untuk memproduksi mold dan dies. Salah satu material yang digunakan dalam industri pembuatan mold adalah AISI P20. Pada proses pembuatan mould menggunakan EDM sinking perlu memperhatikan laju pengerjaan material yang memiliki karakteristik kualitas semakin besar nilainya maka semakin baik. Nilai laju pengerjaan material yang besar dapat meminimalkan biaya produksi. Metode Taguchi digunakan dalam penelitian ini untuk menghasilkan nilai optimal laju pengerjaan material. Desain eksperimen menggunakan orthogonal array $\mathrm{L}_{18}$ untuk mengombinasikan empat variabel proses yaitu jenis elektroda, gap voltage, on time, dan off time. Berdasarkan hasil analisis diperoleh setting parameter untuk laju pengerjaan material yang optimal menggunakan tembaga, gap voltage 40 volt, on time $150 \mu \mathrm{s}$, dan off time $20 \mu \mathrm{s}$.
\end{abstract}

Kata Kunci : EDM Sinking, Laju Pengerjaan Material, Taguchi

\section{PENDAHULUAN}

Proses permesinan non-konvensional yang menunjang industri manufaktur salah satunya adalah Electrical Discharge Machining (EDM). Proses Electrical Discharge Machining (EDM) menggunakan sejumlah loncatan bunga api listrik pada celah antara elektroda dan benda kerja yang terisi dengan cairan dielektrik. Energi panas dihasilkan akibat dari loncatan bunga api yang akan menyebabkan terjadinya pelelehan lokal pada benda kerja dan elektroda, yang kemudian terbawa keluar oleh cairan dielektrik yang berada pada celah di antara benda kerja dan elektroda. Energi panas yang dihasilkan oleh saluran plasma antara elektroda dan benda kerja, berkisar $8000^{\circ} \mathrm{C}$ sampai $12.000^{\circ} \mathrm{C}$, dan dapat mencapai hingga suhu $20.000^{\circ} \mathrm{C}$ [1], [2].
Berdasarkan penjelasan tersebut EDM sangat baik digunakan untuk proses pengerjaan pada benda kerja yang memiliki kekerasan material sangat tinggi dan sulit atau bahkan tidak mampu dikerjakan dengan proses pemesinan konvensional.

EDM Sinking merupakan salah satu jenis EDM yang digunakan untuk pembuatan komponen mould, dan dies. AISI P20 adalah baja yang biasa digunakan sebagai untuk cetakan plastik, kerangka plastic pressure dies, hydro forming tool karena sifatnya yang keras dan tahan terhadap panas. Baja perkakas AISI P20 adalah baja yang memiliki tensile strength yang tinggi sehingga tahan terhadap puntiran dan tarikan, sifat mampu mesin dan sifat tahan aus yang baik. Tingkat kekerasan baja perkakas AISI P20 dapat meningkat setelah 
mendapatkan perlakuan panas hingga mencapai 51 HRC [3].

Metode Taguchi merupakan perancangan percobaan untuk menghasilkan kombinasi faktor dan level yang dapat dikendalikan untuk memperbaiki kualitas produk. Selain itu juga dapat meningkatkan produktivitas yaitu waktu pengerjaan yang singkat dengan biaya proses yang minimal [4].

Dewangan, dkk [3], melakukan penelitian untuk mengoptimalkan material removal rate (MRR) dan tool wear rate (TWR) menggunakan Taguchi Grey Relational Analysis. Penelitian tersebut menggunakan elektroda tembaga dan material AISI P20 yang menerapkan metode pembilasan geram impulse flushing. Material removal rate (MRR) dipengaruhi oleh tool lift time dan work time. Tool wear rate (TWR) dipengaruhi arus dan meningkat secara konstan dipengaruhi oleh worktime. Dari penelitian tersebut didapatkan hasil kombinasi parameter untuk optimasi secara serentak yaitu arus (Ip) 8A, pulse on time (Ton) $500 \mu \mathrm{s}$, tool lift time (Tup) $0 \mathrm{~s}$, work time $(\mathrm{Tw}) 1 \mathrm{~s}$, dan inter electrode gap (IEG) $170 \mu \mathrm{m}$.

Terdapat sebuah studi tentang optimasi multirespon proses permesinan EDM pada AISI D2 Tool Steel menggunakan metode Taguchi-Grey-Fuzzy. Berdasarkan hasil ANOVA, gap voltage dan on time merupakan parameter yang paling signifikan mempengaruhi material removal rate dan surface roughness. Setelah percobaan konfirmasi didapatkan material removal rate meningkat dari 34,68048 menjadi $39,52387 \mathrm{~mm}^{3} / \mathrm{min}$ dan surface roughness menurun 8,58 menjadi 5,37 $\mu \mathrm{m}$ [5].

Srinivasan, dkk [6], meneliti parameter yang berpengaruh terhadap electrode wear rate (EWR) dan material removal rate (MRR). Penelitian tersebut menggunakan material keramik yaitu $\mathrm{Si}_{3} \mathrm{~N}_{4}-\mathrm{T}_{\mathrm{i}} \mathrm{N}$ untuk benda kerja dan elektroda dari tembaga. Didapatkan kesimpulan bahwa MRR meningkat ketika voltage dan current meningkat dan EWR menurun ketika current dan pulse on time meningkat. Serta perubahan pulse on time tidak mempengaruhi MRR.

Penelitian lain mengenai optimasi dilakukan Bahgat, dkk untuk mendapatkan nilai material removal rate (MRR) yang besar dengan kekasaran permukaan dan electrode wear ratio (EWR) yang rendah pada material H13. Penelitian tersebut menggunakan metode Taguchi dengan variasi parameter seperti peak current (Ip), pulse on time (Ton), dan jenis elektroda. Material elektroda dari grafit, tembaga, dan kuningan yang biasa digunakan pada permesinan EDM. Berdasarkan ANOVA, peak current (Ip) menggunakan elektroda tembaga merupakan faktor paling berpengaruh pada EWR dan MRR. Sedangkan jenis elektroda dan pulse on time kurang memberikan pengaruh pada MRR. Parameter untuk menghasilkan MRR yang optimal pada H13 menggunakan tembaga, nilai peak current yaitu 14A, dan pulse on time sebesar $150 \mu$ s [7].

Pada proses EDM sinking, pengikisan material terjadi pada benda kerja. Semakin meningkatnya frekuensi bunga api maka laju erosi akan tinggi yang pada akhirnya akan menghasilkan laju pengejaan material yang lebih besar. Pada proses pembuatan mould perlu memperhatikan laju pengerjaan material untuk mendapatkan biaya proses yang minimal serta menghasilkan produk berkualitas ditinjau dari kekasaran pada benda kerja. Laju pengerjaan material memiliki karakteristik kualitas semakin besar semakin baik.

Penelitian ini bertujuan untuk mendapatkan nilai optimal laju pengerjaan material dengan mengombinasikan parameter pada proses EDM sinking. Desain percobaan menggunakan metode Taguchi. Hasil percobaan dianalisis dengan signal-to-noise ratio (Rasio $\mathrm{S} / \mathrm{N}$ ) dan ANOVA. 


\section{METODOLOGI PENELITIAN}

\section{Alat dan Bahan}

Alat yang diperlukan seperti mesin EDM sinking Ariztech ZNC LS 550 untuk percobaan ditunjukkan pada Gambar 1, timbangan digital dengan kapasitas 500 gram dengan ketelitian 0,01 gram. Bahan yang digunakan dalam penelitian ini antara lain AISI P20 sebagai benda kerja dengan dimensi $25 \mathrm{~mm} \times 25 \mathrm{~mm} \times 20 \mathrm{~mm}$, elektroda tembaga dan grafit dengan dimensi permukaannya $13 \mathrm{~mm} \times 13 \mathrm{~mm}$.

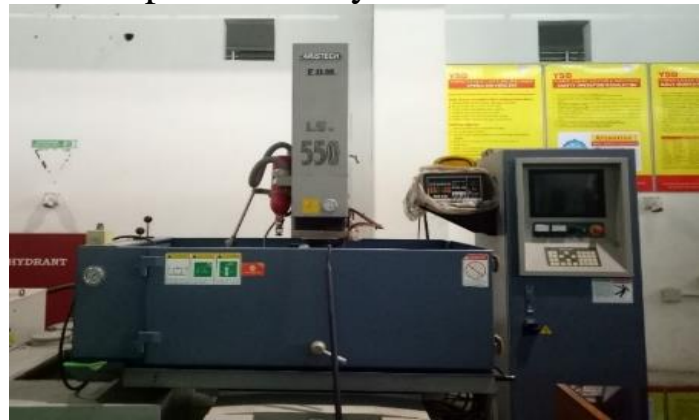

Gambar 1. EDM Sinking Ariztech ZNC LS 550 Variabel Penelitian

Variabel dalam sebuah penelitian memiliki pengaruh yang cukup signifikan terhadap hasil percobaan. Variabel bebas atau variabel proses (independent variable) merupakan variabel yang nilainya dapat dikendalikan dan ditentukan oleh peneliti berdasarkan tujuan dan pertimbangan-pertimbangan lainnya. Variabel bebas yang digunakan dalam penelitian ini adalah gap voltage (volt), on time ( $\mu \mathrm{s})$, off time $(\mu \mathrm{s})$, dan jenis elektroda.

Variabel Respon (dependent variable) merupakan variabel yang diamati dalam penelitian dan nilainya dipengaruhi oleh variabel bebas serta hasilnya dapat diketahui setelah dilakukan percobaan. Variabel respon yang diamati adalah laju pengerjaan material (MRR) yang dinyatakan dalam satuan gram/menit.

Laju pengerjaan material (MRR) didefinisikan sebagai berat material benda kerja yang hilang selama durasi proses permesinan. MRR dapat dihitung menggunakan persamaan berikut ini:

$$
M R R=\frac{W_{w b}-W_{w a}}{t}
$$

$\mathrm{W}_{\text {wb }}$ adalah berat benda kerja sebelum proses permesinan (gram). $\mathrm{W}_{\text {wa }}$ adalah berat benda kerja dan elektroda sesudah proses permesinan (gram) sedangkan $t$ merupakan waktu proses permesinan (menit). Waktu proses permesinan dapat diketahui melalui total time pada layar panel mesin EDM seperti yang ditunjukkan pada gambar 2 .

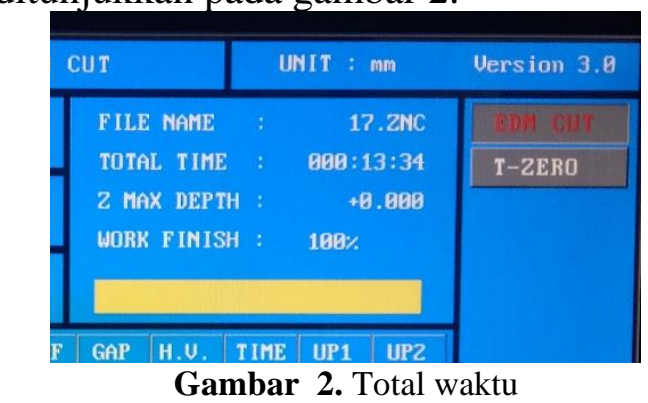

\section{Rancangan Percobaan}

Matriks khusus pada metode Taguchi disebut orthogonal array yang digunakan untuk menentukan jumlah percobaan minimal yang dapat memberikan informasi sebanyak mungkin semua faktor yang mempengaruhi parameter. Penentuan orthogonal array berdasarkan jumlah faktor, derajat kebebasan, dan level faktor.

Perhitungan derajat kebebasan untuk menentukan jumlah eksperimen yang akan dilakukan untuk menyelidiki faktor yang diamati. Derajat kebebasan level faktor $\left(\mathrm{DF}_{\mathrm{fl}}\right)$ dan derajat kebebasan orthogonal array $\left(\mathrm{DF}_{\mathrm{mo}}\right)$ dihitung menggunakan persamaan berikut :

$$
\begin{aligned}
& D F_{f l}=\text { Jumlah level }-1 \\
& D F_{m o}=\text { total percobaan }-1
\end{aligned}
$$

Faktor-faktor yang ditentukan dalam penelitian ini diduga memiliki pengaruh terhadap respon laju pengerjaan . Tabel 1 menunjukkan nilai faktor dan levelnya.

Tabel 1. Penetapan Faktor dan Level

\begin{tabular}{lccc}
\hline Faktor & Level 1 & Level 2 & Level3 \\
\hline $\begin{array}{l}\text { Jenis } \\
\text { elektroda }\end{array}$ & Tembaga & Grafit & - \\
\hline $\begin{array}{l}\text { Gap } \\
\text { Voltage }\end{array}$ & 30 & 40 & 50 \\
\hline On time & 150 & 180 & 250 \\
\hline Off time & 20 & 40 & 60 \\
\hline
\end{tabular}


Derajat kebebasan untuk setiap faktor dapat dilihat pada Tabel 2. Berdasarkan Tabel 2, terdapat satu faktor dengan derajat kebebasan 1, dan tiga faktor lainnya memiliki derajat kebebasan 2 sehingga derajat kebebasan jumlah total derajat kebebasan adalah 7 .

Tabel 2. Derajat Kebebasan

\begin{tabular}{lcc}
\hline Faktor & $\begin{array}{l}\text { Jumlah } \\
\text { level }\end{array}$ & $\begin{array}{l}\text { Derajat } \\
\text { kebebasan (DF) }\end{array}$ \\
\hline Jenis elektroda & 2 & 1 \\
\hline Gap Voltage & 3 & 2 \\
\hline On time & 3 & 2 \\
\hline Off time & 3 & 2 \\
\hline \multicolumn{2}{c}{ jumlah } & 7 \\
\hline
\end{tabular}

Matriks orthogonal array $\mathrm{L}_{18}\left(2^{1} \times 3^{3}\right)$ digunakan dalam penelitian ini yang ditunjukkan pada Tabel 2. Matriks tersebut memiliki total eksperimen sebanyak 18 kali dengan terdapat 1 faktor yaitu jenis elektroda dengan 2 level dan 3 lainnya yaitu gap voltage, on time, off time dengan 3 level.

Tabel 3. Rancangan Percobaan

\begin{tabular}{lrrrr}
\hline Komb. & $\begin{array}{r}\text { Jenis } \\
\text { Elektroda }\end{array}$ & $\begin{array}{r}\text { Gap } \\
\text { Voltage }\end{array}$ & $\begin{array}{r}\text { On } \\
\text { time }\end{array}$ & $\begin{array}{r}\text { Off } \\
\text { time }\end{array}$ \\
\hline 1 & Tembaga & 30 & 150 & 20 \\
\hline 2 & Tembaga & 30 & 180 & 40 \\
\hline 3 & Tembaga & 30 & 250 & 60 \\
\hline 4 & Tembaga & 40 & 150 & 20 \\
\hline 5 & Tembaga & 40 & 180 & 40 \\
\hline 6 & Tembaga & 40 & 250 & 60 \\
\hline 7 & Tembaga & 50 & 150 & 40 \\
\hline 8 & Tembaga & 50 & 180 & 60 \\
\hline 9 & Tembaga & 50 & 250 & 20 \\
\hline 10 & Grafit & 30 & 150 & 60 \\
\hline 11 & Grafit & 30 & 180 & 20 \\
\hline 12 & Grafit & 30 & 250 & 40 \\
\hline 13 & Grafit & 40 & 150 & 40 \\
\hline 14 & Grafit & 40 & 180 & 60 \\
\hline 15 & Grafit & 40 & 250 & 20 \\
\hline 16 & Grafit & 50 & 150 & 60 \\
\hline 17 & Grafit & 50 & 180 & 20 \\
\hline 18 & Grafit & 50 & 250 & 40 \\
\hline
\end{tabular}

Orthogonal array harus memiliki derajat kebebasan yang sama atau lebih besar daripada total derajat kebebasan faktor yang telah ditetapkan. Pada perhitungan Orthogonal array menggunakan persamaan 3 , nilai derajat kebebasannya yaitu 17 yang lebih besar perhitungan derajat kebebasan pada level faktor. Maka rancangan percobaan tersebut dapat dinyatakan layak.

\section{Metode Taguchi}

Pengolahan data pada penelitian ini menggunakan metode Taguchi. Metode Taguchi diperkenalkan oleh Dr. Genichi Taghuci tahun 1940 yang merupakan metodologi dalam bidang teknik yang bertujuan untuk memperbaiki kualitas produk maupun proses serta dapat menekan biaya dan sumber daya seminimal mungkin. Sasaran metode Taguchi adalah peningkatan kualitas produk, dengan mencari faktor-faktor yang berpengaruh terhadap kualitas, lalu memisahkannya kedalam faktor kendali dan faktor tidak terkendali (noise) [8], [9]. Hasil percobaan dianalisis dengan Signal to Noise Ratio ( $\mathrm{S} / \mathrm{N})$ dan analysis of variance (ANOVA) untuk menentukan faktor-faktor dan level faktor yang paling berpengaruh terhadap respon. Berikut tahapan pengolahan data menggunakan metode Taguchi:

1. Rasio $\mathrm{S} / \mathrm{N}$ : Rasio $\mathrm{S} / \mathrm{N}$ atau rasio signal to noise digunakan untuk meminimalkan sensitivitas karakteristik kualitas terhadap faktor gangguan. Terdapat tiga jenis rasio $\mathrm{S} / \mathrm{N}$ yang bergantung pada karakteristik kualitas yang diinginkan, yaitu smaller is better, larger is better, dan nominal is better. Respon laju pengerjaan material menggunakan rasio $\mathrm{S} / \mathrm{N}$ larger is better dapat diperoleh menggunakan persamaan berikut:

$$
\begin{aligned}
\frac{S}{N} \text { ratio }=-10 \log \left[\frac{1}{n} \sum_{i=1}^{n} \frac{1}{y_{i}^{2}}\right] \\
\text { Keterangan: } \mathrm{n}=\text { jumlah replikasi } \\
\mathrm{y}=\text { data percobaan }
\end{aligned}
$$

2. Analysis of Variance (ANOVA)

ANOVA digunakan untuk mengetahui faktor yang berpengaruh terhadap variabel respon. ANOVA terdiri dari perhitungan derajat kebebasan (DF), jumlah kuadrat (sum of square, SS), kuadrat tengah (mean of square, MS), dan $\mathrm{F}$ hitung (F-value) sesuai dengan persamaan berikut ini:

a. Jumlah kuadrat faktor A : 


$$
\begin{aligned}
& S S_{A}=\left[\sum_{i=1}^{K A}\left(\frac{A_{i}^{2}}{n_{A i}}\right)\right]-\frac{T^{2}}{n} \\
& S S_{\text {faktor }}=S S_{A}+\cdots+S S_{n}
\end{aligned}
$$

b. Jumlah kuadrat total :

$$
S S_{T}=\sum y^{2}
$$

c. Jumlah kuadrat rata-rata :

$$
S S_{m}=n x \bar{y}^{2}
$$

d. Jumlah kuadrat error :

$$
S S_{E}=S S_{T}-S S_{m}-S S_{\text {faktor }}
$$

e. Kuadrat tengah :

$$
\begin{aligned}
& M S_{A}=\frac{S S_{A}}{D F_{A}} \\
& M S_{\text {Error }}=\frac{S S_{A}}{D F_{\text {error }}}
\end{aligned}
$$

f. F-value:

$$
F=\frac{M S_{A}}{M S(\text { error })}
$$

Keterangan :

$\mathrm{K}_{\mathrm{A}}=$ jumlah level faktor $\mathrm{A}$

$\mathrm{A}_{\mathrm{i}}=$ level ke $\mathrm{i}$ faktor $\mathrm{A}$

$\mathrm{n}_{\mathrm{Ai}}=$ jumlah percobaan level ke $\mathrm{i}$ faktor $\mathrm{A}$

$\mathrm{T}=$ Jumlah seluruh nilai data

$\mathrm{n} \quad=$ banyak data keseluruhan

$\mathrm{SS}_{\mathrm{A}}=$ sum square faktor $\mathrm{A}$

$\mathrm{SS}_{\mathrm{n}}=$ sum square faktor ke $\mathrm{n}$

$\mathrm{y}^{2}=$ rata-rata kuadrat setiap percobaan

$\bar{y}^{2}=$ rata-rata kuadrat seluruh percobaan

\section{HASIL PENELITIAN}

\section{Hasil Percobaan}

Percobaan dilakukan secara acak dengan maksud untuk menyebarkan faktor-faktor sehingga terdapat kehomogenan pengaruh dari setiap perlakuan. Replikasi dilakukan sebanyak 2 kali. Berat benda kerja diukur terlebih dahulu sebelum melakukan percobaan. Setelah dilakukan percobaan dengan pemakanan sedalam $0,5 \mathrm{~mm}$, kemudian berat benda kerja diukur kembali. Pengukuran berat dilakukan sebanyak 3 kali dalam setiap 18 percobaan. Kemudian data tersebut dirata-rata dan dinyatakan sebagai berat benda kerja yang akan digunakan dalam perhitungan laju keausan elektroda. Data berat elektroda dinyatakan dalam satuan gram. Perhitungan laju pengerjaan material (MRR) menggunakan persamaan 1. Nilai hasil perhitungan MRR selengkapnya dapat dilihat pada Tabel 4.

\section{Pengolahan Data}

Karakteristik kualitas respon laju pengerjaan material adalah larger is better karena menginginkan nilai maksimal. Perhitungan rasio S/N larger is better sesuai persamaan 2. Contoh perhitungannya pada tiga kombinasi pertama adalah sebagai berikut:

a. Kombinasi 1

$$
\begin{aligned}
\mathrm{S} / \mathrm{N}_{1} & =-10 \log \left[\frac{1}{2} \times\left(\frac{1}{0,0444^{2}}+\frac{1}{0,0468^{2}}\right)\right] \\
& =-26,8275
\end{aligned}
$$

b. Kombinasi 2

$$
\begin{aligned}
\mathrm{S} / \mathrm{N}_{2} & =-10 \log \left[\frac{1}{2} \times\left(\frac{1}{0,0584^{2}}+\frac{1}{0,0569^{2}}\right)\right] \\
& =-24,7874
\end{aligned}
$$

c. Kombinasi 3

$$
\begin{aligned}
\mathrm{S} / \mathrm{N}_{3} & =-10 \log \left[\frac{1}{2} \times\left(\frac{1}{0,0389^{2}}+\frac{1}{0,0390^{2}}\right)\right] \\
& =-28,1994
\end{aligned}
$$

Data hasil perhitungan rasio $\mathrm{S} / \mathrm{N}$ selengkapnya pada Tabel 4 sebagai berikut:

Tabel 4. Hasil Percobaan dan rasio S/N

\begin{tabular}{lrrr}
\hline Komb. & Replikasi 1 & Replikasi 2 & Rasio S/N \\
\hline 1 & 0,0444 & 0,0468 & $-26,8275$ \\
\hline 2 & 0,0584 & 0,0569 & $-24,7874$ \\
\hline 3 & 0,0389 & 0,0390 & $-28,1994$ \\
\hline 4 & 0,0676 & 0,0691 & $-23,3050$ \\
\hline 5 & 0,0553 & 0,0552 & $-25,1536$ \\
\hline 6 & 0,0421 & 0,0411 & $-27,6232$ \\
\hline 7 & 0,0613 & 0,0606 & $-24,3026$ \\
\hline 8 & 0,0377 & 0,0382 & $-28,4208$ \\
\hline 9 & 0,0595 & 0,0597 & $-24,5002$ \\
\hline 10 & 0,0289 & 0,0321 & $-30,3532$ \\
\hline 11 & 0,0518 & 0,0517 & $-25,7249$ \\
\hline 12 & 0,0207 & 0,0203 & $-33,7709$ \\
\hline 13 & 0,0693 & 0,0667 & $-23,3577$ \\
\hline 14 & 0,0432 & 0,0407 & $-27,5549$ \\
\hline 15 & 0,0341 & 0,0335 & $-29,4169$ \\
\hline 16 & 0,0470 & 0,0466 & $-26,5936$ \\
\hline 17 & 0,0404 & 0,0405 & $-27,8628$ \\
\hline 18 & 0,0258 & 0,0256 & $-31,8044$ \\
\hline & & &
\end{tabular}

Setelah mengetahui nilai rasio $\mathrm{S} / \mathrm{N}$, kemudian dilakukan perhitungan Analysis of Variance (ANOVA). Perhitungan ANOVA menggunakan persamaan 4 sampai 11. Tabel 5 menunjukkan hasil 
perhitungan derajat kebebasan (DF), jumlah kuadrat (sum of square, SS), kuadrat tengah (mean of square, MS), dan F-value.

Tabel 5. ANOVA

\begin{tabular}{lrrrc}
\hline Faktor & DF & SS & MS & $\begin{array}{c}\text { F- } \\
\text { value }\end{array}$ \\
\hline $\begin{array}{l}\text { Jenis } \\
\text { Elektroda }\end{array}$ & 1 & 30,212 & 30,212 & 6,434 \\
\hline $\begin{array}{l}\text { Gap } \\
\text { Voltage }\end{array}$ & 2 & 14,657 & 7,329 & 1,561 \\
\hline On Time & 2 & 38,668 & 19,334 & 4,117 \\
\hline Off Time & 2 & 10,282 & 5,141 & 1,095 \\
\hline Error & 10 & 46,958 & 4,696 & \\
\hline Total & 17 & 140,777 & & \\
\hline
\end{tabular}

Dari hasil ANOVA dilakukan pengujian hipotesis. Pengujian hipotesis menggunakan distribusi F. Pengujian distribusi $F$ adalah rasio variansi yang disebabkan oleh masing-masing faktor dan error. Nilai F (F-value) yang diperoleh dalam analisis dibandingkan dengan nilai dari F-tabel standar untuk tingkat signifikansi statistik tertentu [10]. Pengujian hipotesis dengan distribusi $\mathrm{F}$ dilakukan pada masing masing faktor menggunakan F-tabel dengan tingkat kepercayaan sebesar $95 \%$ dan taraf signifikansi $(\alpha)$ sebesar 0,05 . Hipotesis pengujian adalah sebagai berikut:

$\mathrm{H}_{0}$ : Tidak ada pengaruh faktor terhadap respon

$\mathrm{H}_{1}$ : Ada pengaruh faktor terhadap respon Keputusan :

Jika F-value > F-tabel maka hipotesis awal $\left(\mathrm{H}_{0}\right)$ ditolak dan dapat disimpulkan bahwa faktor berpengaruh terhadap respon. Sebaliknya, jika F-value < F-tabel maka hipotesis awal $\left(\mathrm{H}_{0}\right)$ diterima maka disimpulkan bahwa faktor tidak berpengaruh terhadap respon. Berikut ini merupakan pengujian hipotesis menggunakan distribusi $\mathrm{F}$ pada masingmasing faktor yang dapat dilihat pada Tabel 6.

Berdasarkan Tabel 6 diketahui bahwa hasil pengujian hipotesis menggunakan distribusi $\mathrm{F}$ dengan tingkat kepercayaan sebesar $95 \%$ dan taraf signifikansi $(\alpha)$ sebesar 0,05 bahwa faktor jenis elektroda dan on time memberikan pengaruh secara signifikan terhadap respon. Sedangkan gap voltage dan off time tidak memberikan pengaruh yang signifikan terhadap respon.

Tabel 6. Pengujian Hipotesis

\begin{tabular}{lrrr}
\hline Faktor & F-Value & F Tabel & Keputusan \\
\hline $\begin{array}{l}\text { Jenis } \\
\text { Elektroda }\end{array}$ & 6,434 & 4,9646 & $\mathrm{H}_{0}$ Ditolak \\
\hline $\begin{array}{l}\text { Gap } \\
\text { Voltage }\end{array}$ & 1,561 & 4,1028 & $\mathrm{H}_{0}$ Diterima \\
\hline On Time & 4,117 & 4,1028 & $\mathrm{H}_{0}$ Ditolak \\
\hline Off Time & 1,095 & 4,1028 & $\mathrm{H}_{0}$ Diterima \\
\hline
\end{tabular}

Penentuan faktor dan level optimum terhadap respon laju pengerjaan material menggunakan nilai dari rasio S/N. Berikut adalah perhitungan untuk menentukan parameter optimum.

a. Parameter Jenis Elektroda (E)

Parameter jenis elektroda level 1 terdapat pada kombinasi 1 sampai 9.

$$
\begin{aligned}
\mathrm{E}_{1}= & {[(-26,8275)+(-24,7874)+} \\
& (-28,1994)+(-23,3050)+ \\
& (-25,1536)+(-27,6232)+ \\
& (-24,3026)+(-28,4208)+ \\
& (-24,5002)] \times \frac{1}{9} \\
= & -25,902
\end{aligned}
$$

Parameter jenis elektroda level 2 terdapat pada kombinasi 10 sampai 18.

$$
\begin{aligned}
\mathrm{E}_{2}= & {[(-30,3532)+(-25,7249)+} \\
& (-33,7709)+(23,3577)+ \\
& (-27,5549)+(-29,4169)+ \\
& (-26,5936)+(-27,8628)+ \\
& (-31,8044)] \times \frac{1}{9} \\
= & -28,493
\end{aligned}
$$

b. Parameter gap voltage (GV)

Parameter gap voltage level 1 terdapat pada kombinasi 1,2,3.10,11, dan 12 .

$$
\begin{aligned}
\mathrm{GV}_{1}= & {[(-26,8275)+(-24,7874)+} \\
& (-28,1994)+(-30,3532)+ \\
& (-25,7249)+(-33,7709)] \times \frac{1}{6} \\
= & -28,277
\end{aligned}
$$

Parameter gap voltage level 2 terdapat pada percobaan $4,5,6,13,14$, dan 15.

$\mathrm{GV}_{2}=[(-23,3050)+(-25,1536)+$ 


$$
\begin{aligned}
& (-27,6232)+(-23,3577)+ \\
& (-27,5549)+(-29,4169)] \times \frac{1}{6} \\
= & -26,069
\end{aligned}
$$

Parameter gap voltage level 3 terdapat pada percobaan $7,8,9,16,17$, dan 18 .

$$
\begin{aligned}
\mathrm{GV}_{3}= & {[(-24,3026)+(-28,4208+} \\
& (-24,5002+(-26,5936)+ \\
& (-27,8628)+(-31,8044)] \times \frac{1}{6} \\
= & -27,247
\end{aligned}
$$

c. Parameter on time (TON)

Parameter on time level 1 terdapat pada percobaan $1,4,7,10,13$, dan 16 . $\mathrm{TON}_{1}=[(-26,8275)+(-23,3050)+$

$$
\begin{aligned}
& (-24,3026)+(-30,3532)+ \\
& (-23,3577)+(-26,5936)] \times \frac{1}{6} \\
= & -25,790
\end{aligned}
$$

Parameter on time level 2 terdapat pada percobaan 2,5,8,11,14, dan 17 .

$\mathrm{TON}_{2}=[(-24,7874)+(-25,1536)+$

$$
\begin{aligned}
& (-28,4208)+(-25,7249)+ \\
& (-27,5549)+(-27,8628)] \times \frac{1}{6} \\
= & -26,584
\end{aligned}
$$

Parameter on time level 3 terdapat pada percobaan 3,6,9,12,15, dan 18 . $\mathrm{TON}_{3}=[(-28,1994)+(-27,6232)+$

$$
\begin{aligned}
& (-24,5002)+(-33,7209)+ \\
& (-29,4169)+(-31,8044)] \times \frac{1}{6} \\
= & -29,219
\end{aligned}
$$

d. Parameter off time (TOF)

Parameter off time level 1 terdapat pada percobaan $1,4,9,11,15$, dan 17 .

$$
\begin{aligned}
\mathrm{TOF}_{1}= & {[(-26,8275)+(-23,3050)+} \\
& (-24,5002)+(-25,7249)+ \\
& (-29,4169)+(-27,8628)] \times \frac{1}{6} \\
= & -26,273
\end{aligned}
$$

Parameter off time level 2 terdapat pada percobaan 2,5,7,12,13, dan 18 .

$\mathrm{TOF}_{2}=[(-24,7874)+(-25,1536)+$

$$
(-24,3026)+(-33,7209)+
$$$$
(-23,3577)+(-31,8044)] \times \frac{1}{6}
$$

$$
=-27,196
$$

Parameter off time level 3 terdapat pada percobaan 3,6,8,10,14, dan 16 . $\mathrm{TOF}_{3}=[(-28,1994)+(-27,6232)+$

$$
(-28,4208)+(-30,3532)+
$$

$$
\begin{aligned}
& (-27,5549)+(-26,5936)] \times \frac{1}{6} \\
= & -28,124
\end{aligned}
$$

Tabel 7 menunjukkan hasil perhitungan untuk menentukan parameter optimum. Berdasarkan tabel tersebut, nilai maksimum parameter jenis elektroda berada pada level 1 dengan nilai -25,902, parameter gap voltage pada level 2 dengan nilai -26,069, parameter on time pada level 1 dengan nilai $-25,790$, dan parameter off time pada level 1 dengan nilai -26,273. Delta merupakan selisih nilai terbesar dan terkecil. Sedangkan rank merupakan peringkat berdasarkan delta dari nilainya yang terbesar ke terkecil.

Tabel 7. Parameter Optimum

\begin{tabular}{lrrrr}
\hline & $\begin{array}{r}\text { Jenis } \\
\text { Level }\end{array}$ & $\begin{array}{r}\text { Gap } \\
\text { Elektroda }\end{array}$ & $\begin{array}{r}\text { On } \\
\text { Time }\end{array}$ & $\begin{array}{r}\text { Off } \\
\text { Time }\end{array}$ \\
\hline 1 & $-25,902$ & $-28,277$ & $-25,790$ & $-26,273$ \\
\hline 2 & $-28,493$ & $-26,069$ & $-26,584$ & $-27,196$ \\
\hline 3 & & $-27,247$ & $-29,219$ & $-28,124$ \\
\hline Delta & 2,591 & 2,209 & 3,429 & 1,851 \\
\hline Rank & 2 & 3 & 1 & 4 \\
\hline
\end{tabular}

Gambar 3 menunjukkan grafik untuk faktor pada kondisi optimum. Gambar 3 merupakan main effect plot for SN Ratios. Berdasarkan gambar tersebut, parameter untuk kondisi optimum respon laju pengerjaan material (MRR), yaitu menggunakan jenis elektroda pada level 1 yaitu tembaga, gap voltage pada level 2 dengan nilai 40 volt, on time pada level 1 dengan nilai $150 \mu$ s dan off time pada level 1 dengan nilai $20 \mu \mathrm{s}$.

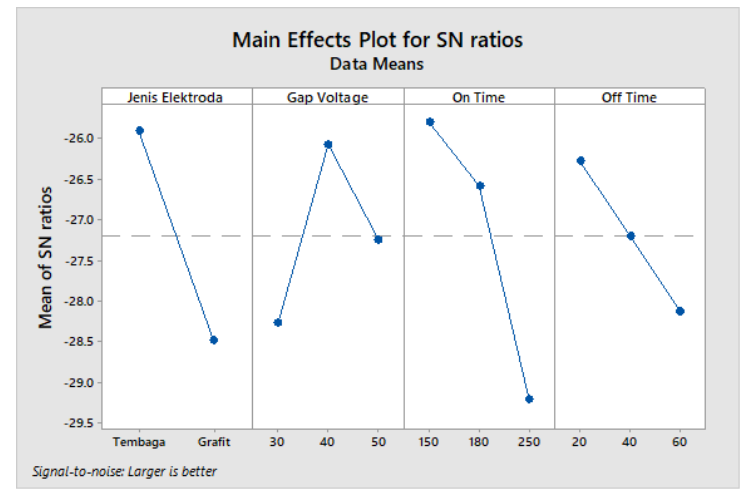

Gambar 3. Grafik Level Faktor Optimal 


\section{KESIMPULAN}

Berdasarkan hasil percobaan dan proses analisa dengan metode Taguchi didapatkan hasil kombinasi parameter pada mesin EDM sinking untuk menghasilkan nilai optimal laju pengerjaan material AISI P20 (larger is better) yaitu menggunakan elektroda tembaga, dan setting parameter gap voltage sebesar 40 volt, on time sebesar $150 \mu \mathrm{s}$, dan off time sebesar $20 \mu \mathrm{s}$. Parameter jenis elektroda dan on time memberikan pengaruh yang cukup signifikan terhadap respon laju pengerjaan material.

\section{UCAPAN TERIMA KASIH}

Penulis mengucapkan terima kasih kepada Pusat Penelitian dan Pengabdian Masyarakat Politeknik Perkapalan Negeri Surabaya yang telah mendanai penelitian ini, serta Laboratorium CNC yang sudah memfasilitasi proses pengambilan data.

\section{DAFTAR PUSTAKA}

[1] Ho, K. H., \& Newman, S. T. (2003). State of the art electrical discharge machining (EDM) . International Journal of Machine Tools and Manufacture,43(13), 1287-1300.

[2] Bose, G. K., \& Mahapatra, K. K. (2015). Multi criteria decision making of machining parameters for Die Sinking EDM Process. International Journal of Industrial Engineering Computations, 6, 241-252.

[3] Dewangan, S. K., \& Biswas, C. (2013). Optimisation of machining parameters using grey relation analysis for EDM with impulse flushing. Int. J. Mechatronics and Manufacturing System,6(2), 144-158.

[4] Lin, J. L., \& Lin, C. L. (2002). The use of the orthogonal array with grey relational analysis to optimize the electrical discharge machining process with multiple performance characteristics. International Journal of Machine Tools and Manufacture,42(2), 237-244.

[5] Soepangkat, B. O. P., Wahyudi, A., \& Pramujati, B. (2014). Multi-Responses Optimization Of Edm Sinking process of Aisi D2 Tool Steel using Taguchi Grey - Fuzzy Method. IPTEK,25(2), 34-40.

[6] Srinivasan, V. P., Palani, P. K., \& Selvarajan, L. (2018). Experimental investigation on electrical discharge machining of ceramic composites $\left(\mathrm{Si}_{3}\right.$ $\mathrm{N}_{4}-\mathrm{T}_{\mathrm{i}} \mathrm{N}$ ) using RSM. International Journal Computational Materials Science and Surface Engineering,7(2), 104-115.

[7] Bahgat, M. M., Shash, A. Y., Abdrabou, M., \& El-mahallawi, I. S. (2019). Influence of process parameters in electrical discharge machining on $\mathrm{H} 13$ die steel. Heliyon, 5(5), 1-6.

[8] Soejanto, I. (2009). Desain Eksperimen dengan Metode Taguchi. Yogyakarta: Graha Ilmu.

[9] Roy, R. K. (2010). A Primer on the Taguchi Method (2nd ed.). Deaborn: Society of Manufacturing Engineers Customer.

[10] Kivak, T., Samtaş, G., \& Cicek, A. (2012). Taguchi Method based Optimisation of Drilling Parameters in Drilling of AISI 316 Steel with PVD Monolayer and Multilayer Coated HSS Drills. Measurement, 45(6), 1547-1557. 